\title{
New data on little known and rare species Atbamanthia japhetica (Nekrutenko et Effendi, 1983) (Lepidoptera, Lycaenidae) from the Caucasus
}

\author{
Новые сведения о малоизученном и редком виде \\ Atbamantbia japhetica (Nekrutenko et Effendi, 1983) \\ (Lepidoptera, Lycaenidae) на Кавказе
}

\author{
D.V. Morgun \\ A.B. Моргун \\ Moscow Centre of Environmental Education, Regional Research and Tourism, Odesskaya Str. 12A, Moscow 117303 Russia. \\ E-mail:d moth@mail.ru. \\ Московский центр экологии, краеведения и туризма, ул. Одесская 12А, Москва 117303 Россия.
}

Key words: Athamanthia japhetica, Lepidoptera, Lycaenidae, distribution, Georgia, fauna.

Ключевые слова: Athamanthia japhetica, Lepidoptera, Lycaenidae, распространение, Грузия, фауна.

\begin{abstract}
New data on the distribution and ecology of the rare Lycaenid species Athamanthia japhetica (Nekrutenko et Effendi, 1939 (Lepidoptera, Lycaenidae) in the Central Caucasus are presented. A comparison of the new material with the specimens of the former known populations is described.
\end{abstract}

Pезюме. Представлены новые сведения о распространении и экологии редкого вида голубянок (Athamanthia japhetica (Nekrutenko et Effendi, 1983) (Lepidoptera, Lycaenidae) в центральной части Кавказа. Описано сравнение особей с особями ранее известных популяций вида.

By present time two species of the genus Athamanthia Zhdanko, 1983 (Lepidoptera, Lycaenidae) are known from the Caucasus region [Bozano, Weidenhoffer, 2001; Tschikolovets, Nekrutenko, 2012]. Athamanthia phoenicura (Lederer, 1870) was found by me several times in the southern part of the Zangezur ridge, where it is represented by ssp. A. p. melicertes Nekrutenko, 1985. It inhabits different types of the arid stony biotopes in the basin of Arax river both in Nakhchevan (Azerbaijan) and Meghri Range in Armenia. The second Caucasian representative of this genus is Athamanthia japhetica (Nekrutenko et Effendi, 1983) had been missed from its first description for a long time, until it was refound and described in details of its ecology and behavior in 2012 by V. Tikhonov. This species was described by Nekrutenko and Effendi [1983] on 28 specimens from Apsheron district, Dizavarchai river valley in Eastern Azerbaijan. The type series was collected in the Dizavarchai valley in $2 \mathrm{~km}$ before the confluence of this river to Tugchai river, at the $14 / 36 \mathrm{~km}$ of the Kilyazy Altyagach highway. Type locality is situated between Kilyazy and Tazakend villages. For about 30 years any new material was not known, and the species distribution was treated as Apsheron peninsula in Caspian area of Azerbaijan [Tuzov et al., 2000]. In 2012 and 2013, V.V. Tikhonov and V.A. Lukhtanov found the population of $A$. japhetica near the type locality in the Tugchai valley, $30 \mathrm{~km}$ SW Kilyazy village, and near Shirvan station.

New population of A. japhetica in Georgia. Until now, A. japhetica was treated as a species of Caspian area of Eastern Azerbaijan, known only by two recently found populations in this area. V. Tschikolovets [2011] wrote that the species range covered arid regions around western part of Caspian Sea in extreme NE Azerbaijan. The distribution in Daghestan (Russia) of the species [Gorbunov, Kosterin, 2007] has not been confirmed.

In 2017 the species was found in the other geographical part of the Great Caucasus the border of Kura basin depression and the southern slope of the Central Great Caucasus, following the Caucasus zonation by Y.P Nekrutenko [1990] who used the F.N. Milkov and N.A. Gvozdetsky's approach [Milkov, Gvozdetsky, 1986]. This population is found at about $425 \mathrm{~km}$ to the west from the last found specimens in Eastern Azerbaijan. A. japhetica was found in the vicinities of Kaspi town in the historical Kartli province of Georgia. Therefore, A. japhetica is a new species and genus for Georgian butterfly fauna. The GPS coordinates of $A$. japhetica in its Georgian locality are N 41 ${ }^{\circ} 57^{\prime} 17^{\prime \prime}$, E $044^{\circ} 25^{\prime} 16^{\prime \prime}$ and the distance between N 41 $57^{\prime} 17^{\prime \prime}, \mathrm{E} 044^{\circ} 25^{\prime} 16^{\prime \prime}$ to $\mathrm{N} 41^{\circ} 57^{\prime} 32^{\prime \prime}, \mathrm{E} 044^{\circ} 24^{\prime} 46^{\prime \prime}$, where it occurs on the slope from 610 to $762 \mathrm{~m}$ a.s.l. However, the Caspian Azerbaijan populations are known from lower altitudes (100$450 \mathrm{~m}$ a.s.l). The species seems to be rare in this area and represents some small compact scattered colonies that localize near the associations of Atraphaxis, the 

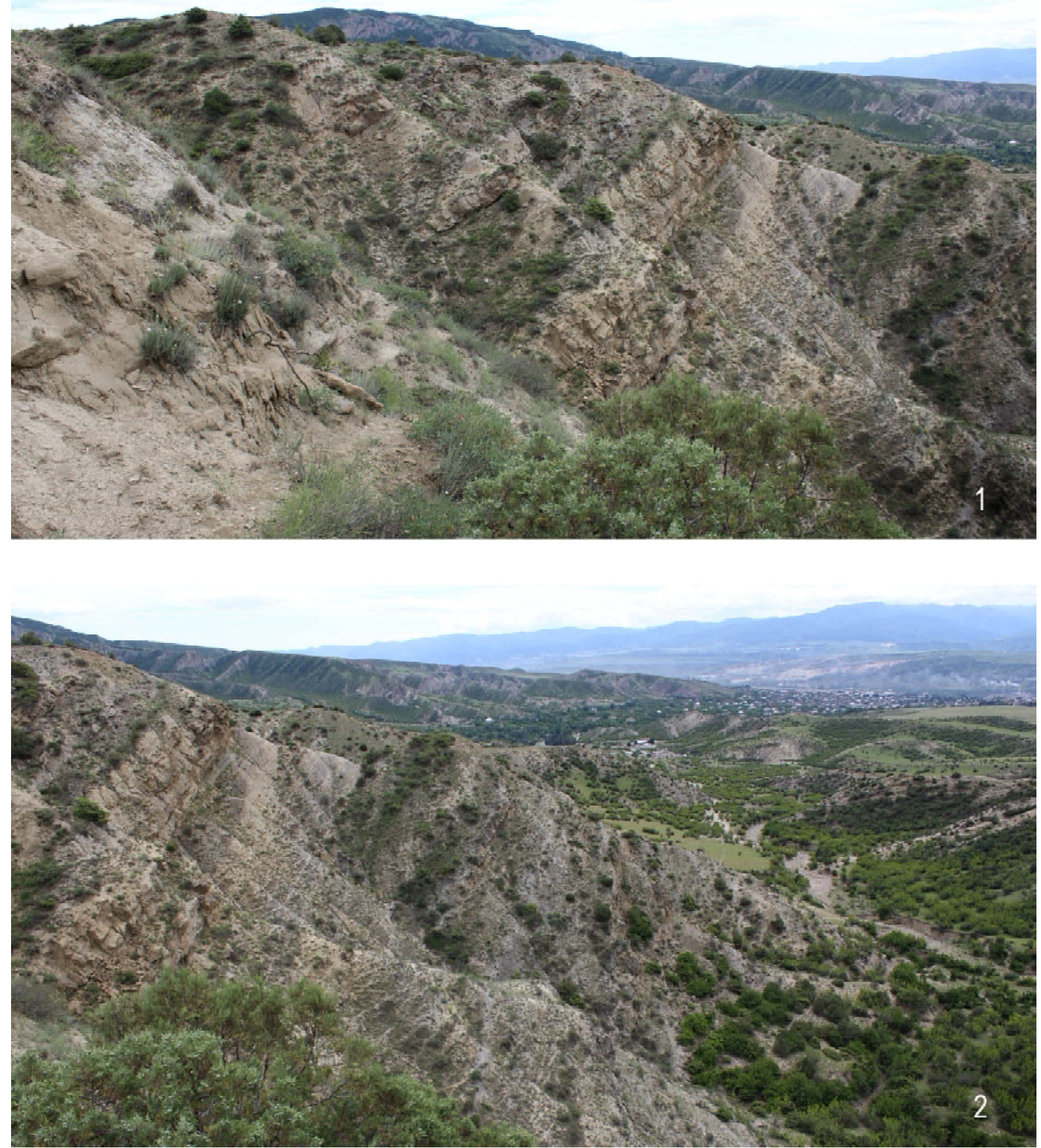

Figs 1-2. The biotopes of Athamanthia japhetica near Kaspi in its Georgian locality.

Рис. 1-2. Биотопы Athamanthia japhetica близ Каспи в Грузии.

probable larval host plant. The behavior and ontogenesis of the species in Azerbaijan were carefully described by V.V. Tikhonov and I.N. Tikhonova [2014]. These authors found out that the larva feeds on Atraphaxis spinosa and described the life cycle of preimaginal stadia. The species was previously found in semi-deserts, arid stony foothills with xerophytic vegetation up to
1000 m [Tschikolovets, Nekrutenko, 2012; Tuzov et al., 2000]. The biotope in its type locality and in the locality of the second found population in Caspian Azerbaijan are similar to the Kaspi vicinities in Georgia, where it occurs in stony, shale and clayey slopes and valleys among low xerophytic grass (figs 1-2). The cited authors mentioned also that $A$. japhetica was flying to- 


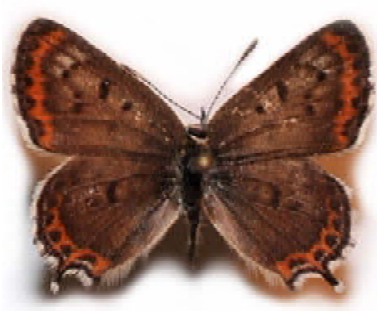

a

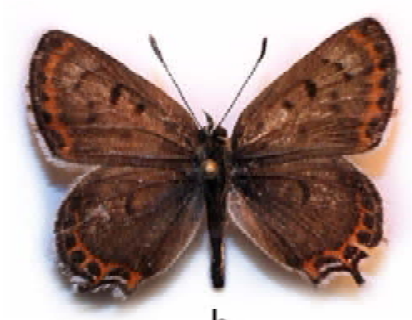

b

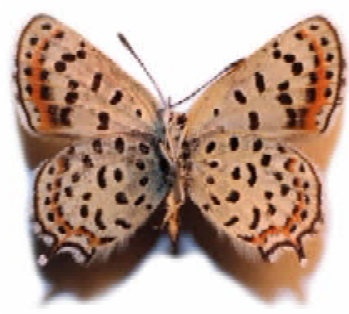

C

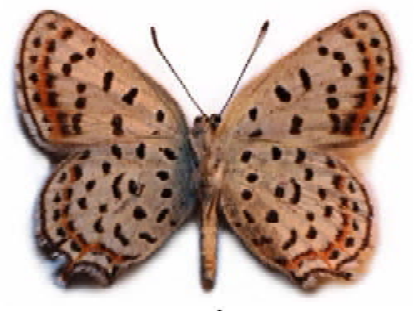

d

Fig. 3. Athamanthia japhetica specimens from Kaspi vicinities (Georgia, Kaspi, 21.06.2017, 23.06.2017, Grigoryev O.A. leg.): $\mathrm{a}, \mathrm{b}$ - wings upperside, $\mathrm{c}, \mathrm{d}$ - wings underside.

Рис. 3. Особи Athamanthia japhetica из окрестностей Каспи (Грузия, Каспи, 21.06.2017, 23.06.2017, Григорьев О.А. lеg.): $\mathrm{a}, \mathrm{b}$ - верхняя сторона крыльев; c, d - нижняя сторона крыльев.

gether with Armenia hyrcanica (Riley, 1939) which was also found with A. japhetica in Georgian locality. Plebeius loweii (Zeller, 1847) was also found sympatrically with these species there. The imagines in Georgia are found fresh in the last decade of June, whereas the preCaspian imagines of $A$. japhetica were mainly observed in the middle and the end of May. Y.P. Nekrutenko and R.M. Effendi wrote that the imagines fly from the May till the beginning of July. The phenological difference of imagines emergence in Georgia can be explained by higher altitudes where the species occurs.

The habitus comparison of A. japhetica specimens. The nominal subspecies $A$. j. japhetica specimens have some obvious and constant features that were stated in its diagnosis. They include the absence of violet tint or suffusion which is inherent to A. phoenicura and some other Athamanthia species; whitish postdiscal area, both orange submarginal band and black spots are well pronounced on the upperside of the wings. The anal lobe is large and orange and white marginal line at anal angle is not constant on the hind wing [Bozano, Weidenhoffer, 2001; Nekrutenko, Effendi, 1983; Tuzov et al., 2000]. According to the original description of the holotype, wings upperside is dark brown, with a continuous orange band embraced by full rows of submarginal and antemarginal spots. The main peculiarity of the wing pattern providing the reliable recognition of this species is the presence on each wing a whitish area with a diffuse margin. On the hind wing the spots of the submarginal row are separated from the black marginal line with a narrow white space. Male genitalia differs slightly from the closest species by the shape of socii, gnathos arms and valvae [Gorbunov, 2001]. The subspecies $A$.j. irghiza (Nekrutenko, 1985) occurs in the South Urals (Orenburg Region, Russia) [Gorbunov, Kosterin, 2007], NW and Central Kazakhstan [Tuzov et al., 2000]

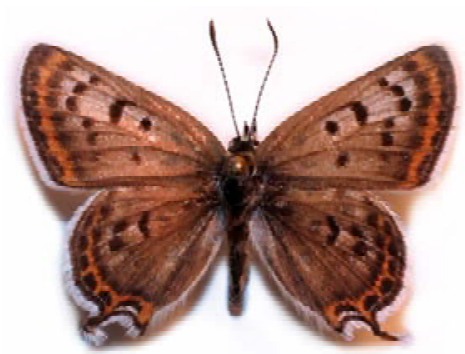

a

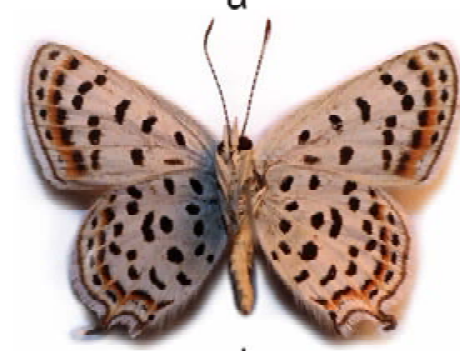

d

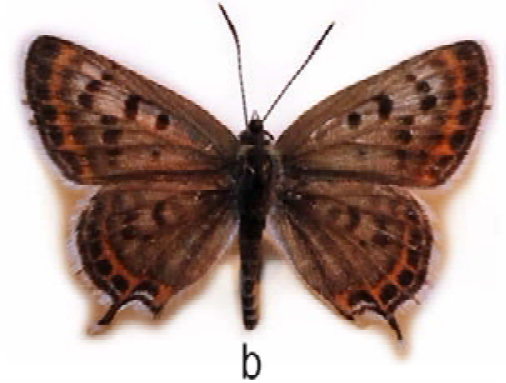

b

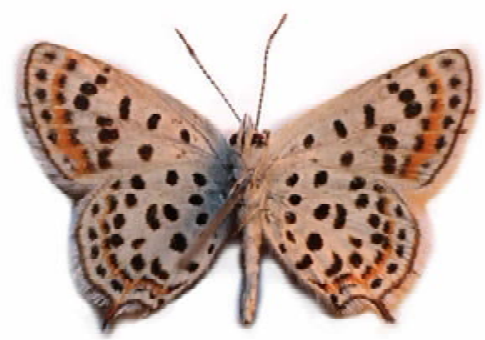

e

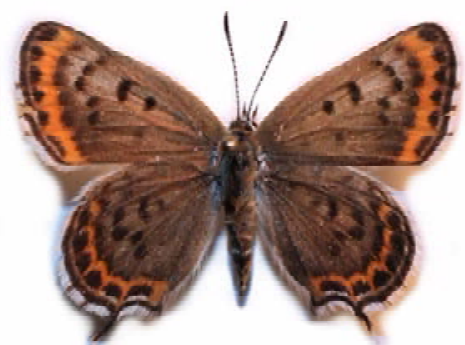

C

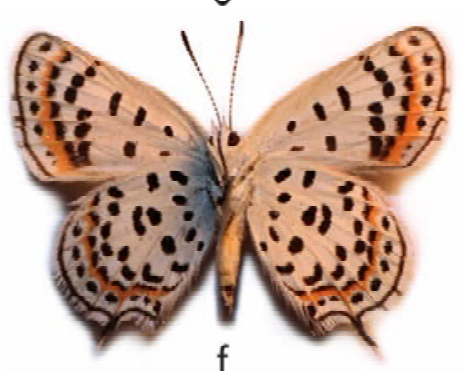

Fig. 4. Athamanthia japhetica specimens from the type locality vicinities (Azerbaijan, Dizavarchai, 17.05.2012, Tikhonov V.V. leg.): $a, b, c-$ wings upperside; $d, e, f-$ wings underside.

Рис. 4. Особи Athamanthia japhetica из окрестностей типового местонахождения (Азербайджан, Аизаварчай, 17.05.2012, Тихонов В.B. leg.): a, b, с - верхняя сторона крыльев; d, e, f - нижняя сторона крыльев. 


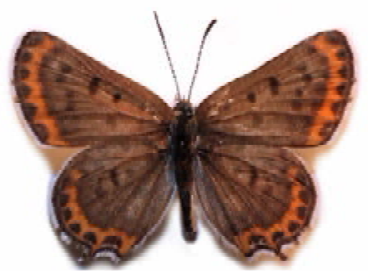

a

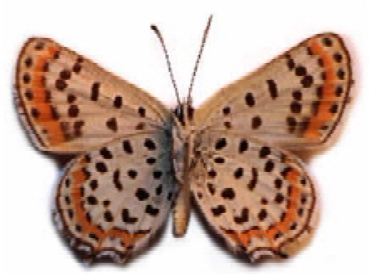

b

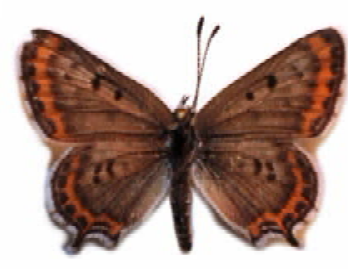

C

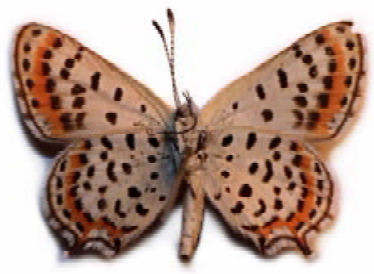

d

Fig. 5. A. japhetica irghiza specimens from West Kazakhstan. Kazakhstan, Atyrau region, Aktologai, 21.05.2005, Dovgailo K.E. leg.: a - wings upperside, b - wings underside. Kazakhstan, Aktobe region, $28 \mathrm{~km}$ SSE Shurbashi, Emba river valley, 25.05.2005, Dovgailo K.E., Rubin N.I. leg.: $\mathrm{c}$ - wings upperside, $\mathrm{d}-$ wings underside.

Рис. 5. Особи А. japhetica irghiza из Западного Казахстана. Казахстан, обцасть Атырау, Актолагай, 21.05.2005, Аовгайло K.E. leg.: a - верхняя сторона крыльев, b - нижняя сторона крыльев. Казахстан, область Актобе, 28 км ЮЮВ Шурбаши, пойма реки Эмбы, 25.05.2005, Аовгайло К.Е., Рубин Н.И. leg.: с - верхняя сторона крыльев, d - нижняя сторона крыльев.

and is characterized by lighter grey-brown males and shorter tails on the hind wing than in nominal A.j. japhetica [Nekrutenko, 1985; Zhdanko, 1993]. The male genitalia structure is practically indistinguishable from the genitalia of the nominal subspecies [Gorbunov, 2001]. The specimens from Georgia have darker ground color and show the absence or reduction of the light postdiscal area that is obvious in Azerbaijan specimens and some $A$.j. irghiza males (figs $3-5$ ). The black spots are not so prominent in the Georgian specimens upperside. The average Georgian specimens are larger than the Azerbaijan and Kazakhstan ones (13-13.5 mm). The underside ground color is more ochre but not chalk white or silvery white (as shown in type diagnosis) colored, with not contrast black spots as it can be seen in specimens of the eastern populations. The tails are well expressed, have a narrow orange border, passing to the anal angle. Anyhow, the common habitus features show the close similarity to the nominal japhetica specimens (figs 3-4).

A.B. Zhdanko [1993] suggested that the limits of the species in Kazakhstan can depend on the distribution of the host plant Atraphaxis spinosa. In this case, this mono-thamnophagous butterfly species associated with the plants of Atraphaxis genus can be found in the other Caucasian localities in future.

\section{Acknowledgements}

I am much indebted to O.A. Grigoryev (Cheboksary, Russia) who provided the material and photos from Kaspi (Georgia) and B. Gavrilov (Veliky Novgorod, Russia) for his assistance. I also express my gratitude to V.V. Tikhonov (Pyatigorsk, Russia) for his materials and data used during the article preparation.

\section{References}

Bozano G.C., Weidenhoffer Z. 2001. The Butterflies of the Palearctic Region. Lycaenidae. Part 1 . Subfamily Lycaeninae. Milano. $62 \mathrm{p}$.

Gorbunov P.Yu. 2001. The Butterflies of Russia: classification, genitalia, keys for identification (Lepidoptera: Hesperioidea et Papilionoidea). Ekaterinburg: Thesis. 320 p. [In Russian].

Gorbunov P.Yu., Kosterin O.E. 2007. The butterflies (Hesperioidea et Papilionoidea) of North Asia (Asian part of Russia) in nature. Vol.II. M.: Rodina, Fodio and Aidis Production House. 408 p. [In Russian].

Milkov F.N., Gvozdetsky N.A. 1986. Physical geography of the USSR. General overview. European part. Caucasus: Textbook for students of geography of special faculties, 5-th edition. M.: Vysshaya shkola. 376 p. [In Russian].

Nekrutenko Yu.P. 1985. New Blue Butterfly Taxa (Lepidoptera, Lycaenidae) from Transcaucasia and Middle Asia. // Vestnik zoologii. No.4. P.29-35.

Nekrutenko Yu.P. 1990. The Butterflies of the Caucasus. Book for identification. Families Papilionidae, Pieridae, Satyridae, Danaidae. Kiev: Naukova dumka. 216 p. (in Russian).

Nekrutenko Yu.P., Effendi R.M. 1983. Review of the Lycaena phoenicurus group (Lepidoptera, Lycaenidae) with description of new species from Azerbaijan // Vestnik zoologii. No.4. P. $8-15$. [In Russian].

Tikhonov V.V., Tikhonova I.N. 2014. To the knowledge of biology of Athamanthia japhetica (Nekrutenko et Effendi, 1983) (Lepidoptera: Lycaenidae) in Azerbaijan // Caucasian Entomological Bull. Vol.10. No.1. P.129-130. [In Russian].

Tschikolovets V., Nekrutenko Yu. 2012. The Butterflies of Caucasus and Transcaucasia (Armenia, Azerbaijan, Georgia and Russian Federation). Kyiv Pardubice: Tshikolovets Publication. 424 p.

Tuzov V.K., Bogdanov P.V., Churkin S.V., Dantchenko A.V., Devyatkin A.L., Murzin V.S., Samodurov G.D., Zhdanko A.B. 2000. Guide to the Butterflies of Russia and Adjacent Territories. Vol. 2. Sofia-Moskow.: Pensoft Publ. 580 p.

Zhdanko A.B. 1993. Systematics, biology and distribution of Lycaenids of the genus Athamanthia Zhd. (Lepidoptera, Lycaenidae) // Entomologicheskoe obozrenie. Vol.72. No.3. P.664-674. [In Russian]. 